\title{
ANALISIS USAHA PEMANFAATAN DAUN KELAPA SAWIT FERMENTASI DENGAN Aspergillus niger DAN LIMBAH PABRIK KELAPA SAWIT TERHADAP PERFORMANS SAPI BALI JANTAN
}

\section{(Analysis of Utilization of Oil Palm Frond Fermented by Aspergillus niger and Oil Palm Mill Waste on Performances of Males Bali Cattle)}

\author{
Dani Jefri ${ }^{1}$, Armyn Hakim Daulay ${ }^{2}$ dan Tri Hesti Wahyuni ${ }^{2}$
}

1. Mahasiswa Program Studi Peternakan Fakultas Pertanian Universitas Sumatera Utara

2. Staf Pengajar Program Studi Peternakan Fakultas Pertanian Universitas Sumatera Utara

\begin{abstract}
Giving oil palmfrond in the feed fermentation gives the economic value and increase profits bali male cattle weaning. This study conducted in Dusun 1 (Sembat) Nagori Marihat District Line Dolok Marlawan Simalungun. This reseach held for three month starting in January 2013 until May 2013. This study used 12 male Bali cattle with a randomized block design, consisting of 4 groups that are based on body weight. There are three treatments i.e. P0 (ration with $25 \%$ fresh oil palm frond), P1(ration with $20 \%$ fermented oil palm frond) and $P 2(30 \%$ ration with fermented oil palm frond).The results showed that the average income is highest at Pltreatment gives a profit of Rp. 2.146.046. -And smallest in the P0 treatment by giving a profit of Rp. 1.570.177. -. The average return cost ratio $(R / C)$ is highest at $P 1$ treatment was 1,52 and the smallest at $1,40 P 0$ treatment. Mean Income Over Feed Cost (IOFC) at the highest P1 treatment of Rp. 2.349.296. -, and the lowest at PO treatment of Rp. 1.794.927. -. The conclusion is that the utilization of oil palm frond fermented by Aspergillus niger can be used as an alternative feed ingredients in bali cattle feed.
\end{abstract}

Keywords: Business analysis, oil palm frond, fermentation, Aspergillus niger, Bali cattle

\begin{abstract}
ABSTRAK
Pemberian pelepah sawit fermentasi dalam pakan memberi nilai ekonomis dan meningkatkan keuntungan penggemukan sapi bali jantan lepas sapih. Penelitian ini akan dilaksanakan di Dusun 1 (sembat) Nagori Marihat Baris Kecamatan Dolok Marlawan Kabupaten Simalungun.Penelitian ini telah dilaksanakan selama tiga bulan yang dimulai pada bulan Januari 2013 sampai Mei 2013. Penelitian ini menggunakan 12 ekor sapi bali jantan dengan rancangan acak kelompok, terdiri atas 4 kelompok yang dibedakan berdasarkan bobot badan sapi. Ada tiga perlakuan yaitu P0 (ransum dengan 25\% pelepah kelapa sawit segar), P1 (ransum dengan $20 \%$ pelepah kelapa sawit fermentasi) dan P2 (ransum dengan 30\% pelepah kelapa sawit fermentasi). Hasil penelitian menunjukkan bahwa rataan laba tertinggi adalah pada perlakuan P1 memberikan keuntungan sebesar Rp. 2.146.046.- dan terkecil pada perlakuan P0 dengan memberikan keuntungan sebesar Rp. 1.570.177.-. Rataan return cost ratio $(\mathrm{R} / \mathrm{C})$ tertinggi adalah pada perlakuan $\mathrm{P} 1$ sebesar 1.52 dan terkecil pada perlakuan $\mathrm{P} 0$ sebesar 1.40. Rataan Income Over Feed Cost (IOFC) tertinggi pada perlakuan P1 sebesar Rp. 2.349.296.- dan yang terendah pada perlakuan P0 sebesar Rp. 1.794.927.-. Kesimpulan adalah pemanfaatan daun kelapa sawit yang difermentasai dengan Aspergillus niger dapat digunakan sebagai bahan pakan alternatif pada pakan sapi bali.
\end{abstract}

Kata kunci : Analisis usaha, pelepah daun kelapa sawit, fermentasi, Aspergillus niger, sapi bali jantan

\section{PENDAHULUAN}

Pembangunan sektor peternakan merupakan bagian dari pembangunan sektor pertanian, dimana sub-sektor ini memiliki peran strategis dalam memenuhi kebutuhan protein hewani. Kebutuhan protein hewani terus meningkat sejalan dengan pertambahan penduduk dan peningkatan taraf hidup masyarakat. Keberhasilan pembangunan ternyata berdampak 
pada perubahan konsumsi masyarakat yang semula lebih banyak mengkomsumsi karbohidrat kearah konsumsi protein seperti daging, telur, dan susu.

Peternakan sapi potong merupakan salah satu sumber daya penghasil bahan makanan berupa daging yang memiliki nilai ekonomis tinggi dan penting artinya dalam kehidupan masyarakat. Kebutuhan masyarakat akan protein hewani yang semakin lama semakin meningkat memberikan suatu keuntungan tersendiri bagi peternak-peternak sapi potong di Indonesia. Adanya perkembangan kota-kota besar, kemajuan ilmu pengetahuan, peningkatan taraf hidup rakyat dan peningkatan pendidikan di negeri kita ini secara tidak langsung pula akan membawa pengaruh baik terhadap perubahan menu makanan yang lebih banyak mengandung protein. Hal ini akan meningkatkan kebutuhan atau permintaan daging, khususnya daging sapi

Demikian pula semakin meningkatnya kebutuhan protein hewani berupa daging sapi. Saat ini usaha produksi pedet atau sapi bakalan (cow calf operation) $99 \%$ dilakukan oleh usaha peternakan rakyat berskala kecil.

Usaha yang biasa dilakukan untuk meminimalisir biaya pakan pada usaha calf cow operation adalah dengan melakukan integrasi dengan usaha pertanian atau perkebunan dimana kedua lokasi tersebut merupakan potensi biomassa lokal sebagai sumber daya pakan yang berlimpah. Integrasi tersebut diharapkan dapat mendekati kondisi zero cost terutama dari segi pakan.

Pelepah sawit dapat diperoleh sepanjang tahun bersamaan panen tandan buah segar. Pelepah kelapa sawit dipanen 1-2 pelepah/panen/pohon. Setiap tahun dapat menghasilkan 22-26 pelepah/tahun dengan rataan berat pelepah daun sawit 4-6 kg/pelepah, bahkan produksi pelepah dapat mencapai 40-50 pelepah/pohon/tahun dengan berat sebesar 4,5 $\mathrm{kg} /$ pelepah (Jalaluddin, 1982; Umiyasih et al., 2002). Hasil limbah kelapa sawit ini merupakan potensi yang cukup besar sebagai pakan ternak ruminansia.

Pelepah daun kelapa sawit memiliki potensi yang besar untuk dijadikan salah satu pakan alternatif. Namun tingginya kandungan serat kasar yang terkandumg pada pelepah daun kelapa sawit menyebabkan rendahnya tingkat kecernaan. Penggunaan Aspergillus niger dalam proses fermentasi diharapkan mampu meningkatkan kecernaan pelepah daun kelapa sawit.

Berdasarkan uraian diatas maka penulis tertarik untuk mengetahui sejauh mana nilai ekonomis pemberian pelepah daun kelapa sawit yang difermentasi dengan Aspergillus niger dalam pakan terhadap pertumbuhan bobot badan sapi Bali. 


\section{BAHAN DAN METODE}

\section{Lokasi dan Waktu Penelitian}

Penelitian ini dilaksanakan di Dusun 1 (Sembat) Nagori Marihat Baris Kecamatan Dolok Marlawan Kabupaten Simalungun. Penelitian ini telah dilaksanakan selama tiga bulan yang dimulai pada bulan Januari 2013 sampai Mei 2013.

\section{Bahan dan Alat Penelitian}

Bahan yang digunakan dalam penelitian ini adalah 12 ekor sapi bali jantan lepas sapih, pakan yang terdiri atas: pelepah daun kelapa sawit fermentasi, bungkil inti sawit, lumpur sawit, dedak padi, onggok, molasses, urea, garam dan ultra mineral, obat-obatan dan air minum.

Alat yang digunakan dalam penelitian ini adalah kandang individual sebanyak 12 unit $(1,5 \mathrm{~m} \times 2 \mathrm{~m})$ beserta perlengkapannya, tempat pakan dan minum, timbangan untuk menimbang berat badan sapi selama penelitian, timbangan dengan kapasitas $1000 \mathrm{~kg}$ dengan kepekaan $1 \mathrm{~kg}$ untuk menimbang konsentrat, kandang jepit yang digunakan pada saat penimbangan bobot badan sapi dilaksanakan, alat kebersihan (ember, sapu, angkong, sabit, tempat sampah), lampu sebagai alat penerangan, kalkulator sebagai alat untuk mempermudah perhitungan, dan alat tulis sebagai alat pencatat data selama penelitian.

\section{Metode Penelitian}

Metode penelitian yang digunakan adalah rancangan acak kelompok (RAK) dengan 3 perlakuan dan 4 kelompok. Perlakuan yang akan diteliti sebagai berikut :

P0 $=$ Pakan dengan 25\% Pelepah Daun Kelapa Sawit Segar

P1 = Pakan dengan 20\% Pelepah Daun Kelapa Sawit Fermentasi

P2= Pakan dengan 30\% Pelepah Daun Kelapa Sawit Fermentasi

Model linier yang digunakan untuk rancangan acak kelompok (RAK) (Hanafiah, 2003) adalah $: \mathbf{Y}_{\mathbf{i j}}=\boldsymbol{\mu}+\mathbf{T}_{\mathbf{i}}+\mathbf{B}_{\mathbf{j}}+\sum_{\mathbf{i j}}$

Keterangan : $\mathrm{Y}_{\mathrm{ij}}=$ Nilai pengamatan dari perlakuan ke-i dan ulangan ke-j

$\mu=$ Nilai tengah umum

$\mathrm{T}_{\mathrm{i}}=$ Pengaruh perlakuan ke- $\mathrm{i}$

$\mathrm{B}_{\mathrm{j}}=$ Pengaruh blok ke- $\mathrm{j}$

$\sum_{\mathrm{ij}}=$ Pengaruh galat dari perlakuan ke-i dan ulangan ke-j 


\section{Parameter Penelitian:}

Analisis Usaha

1. Total Biaya Produksi

Total biaya produksi atau total pengeluaran yaitu biaya-biaya yang dikeluarkan untuk menghasilkan suatu produk, diperoleh dengan cara menghitung : biaya pembelian bibit, sewa kandang dan peralatan, biaya pakan, biaya obat-obatan dan biaya/upah tenaga kerja.

2. Total Hasil Produksi

Total hasil produksi atau total penerimaan yaitu seluruh produk yang dihasilkan dalam kegiatan ekonomi diperoleh dengan cara menghitung : harga jual sapi dan harga jual kotoran sapi.

3. Analisis Laba-Rugi

Analisis ekonomi atau Laba-Rugi dilakukan untuk mengetahui apakah usaha tersebut rugi atau menguntungkan dengan cara menghitung selisih antara total hasil produksi dengan total biaya produksi.

4. Return Cost Ratio (R/C Ratio)

$\mathrm{R} / \mathrm{C}$ Ratio dilakukan untuk mengetahui tingkat efisiensi suatu usaha yaitu dengan cara membagikan total pendapatan dengan total biaya produksi.

5. Income Over Feed Cost (IOFC)

IOFC didapat dengan cara pendapatan usaha peternakan yang didapat dari berat badan ternak (bobot potong-bobot awal) di kali harga ternak/kg dikurangi dengan biaya pakan (total konsumsi pakan $\mathrm{x}$ harga pakan/kg).

\section{HASIL DAN PEMBAHASAN}

\section{Analisis Usaha}

\section{Total Biaya Produksi}

Biaya adalah nilai dari semua korbanan ekonomis yang diperlukan yang tidak dapat dihindarkan, dapat diperkirakan dan dapat diukur untuk menghasilkan sesuatu produk. Biaya bagi perusahaan adalah nilai dari faktor-faktor produksi yang digunakan untuk menghasilkan output (Budiono, 1990). Total biaya produksi atau total pengeluaran yaitu biaya-biaya yang dikeluarkan untuk menghasilkan suatu produk, diperoleh dengan cara menghitung: biaya pembelian sapi, biaya pakan, biaya sewa kandang, biaya obat-obatan dan biaya tenaga kerja. 
Rataan biaya produksi yang tertinggi berdasarkan Tabel 1 di atas terdapat pada perlakuan P2 (pakan dengan 30\% pelepah kelapa sawit fermentasi) sebesar Rp 4.161.786,5 dan yang terendah terdapat pada perlakuan P0 (pakan dengan 25\% pelepah kelapa sawit segar) sebesar Rp 3.912.322,8. Tabel 1 menunjukkan adanya perbedaan biaya produksi dalam pemeliharaan selama penelitian. Hal ini disebabkan karena perbedaan harga pembelian bibit, jumlah pakan yang dikonsumsi lebih banyak demikian juga harga pakan yang juga lebih mahal perkilogramnya tiap perlakuan.

Tabel 1. Rekapitulasi komponen biaya produksi tiap perlakuan selama penelitian (Rp)

\begin{tabular}{ccccccc}
\hline & \multicolumn{6}{c}{ Rataan } \\
\cline { 2 - 7 } Perlakuan & Biaya bibit & $\begin{array}{c}\text { Biaya } \\
\text { pakan }\end{array}$ & $\begin{array}{c}\text { Upah } \\
\text { tenaga } \\
\text { kerja }\end{array}$ & $\begin{array}{c}\text { Biaya } \\
\text { sewa } \\
\text { kandang }\end{array}$ & $\begin{array}{c}\text { Biaya } \\
\text { obat- } \\
\text { obatan }\end{array}$ & $\begin{array}{c}\text { Total biaya } \\
\text { produksi }\end{array}$ \\
\hline P0 & 2.925 .750 & $666.572,8$ & 100.000 & 205.000 & 15.000 & $3.912 .322,8$ \\
P1 & 3.102 .000 & $703.204,3$ & 100.000 & 205.000 & 15.000 & $4.125 .204,3$ \\
P2 & 3.254 .750 & $587.036,5$ & 100.000 & 205.000 & 15.000 & $4.161 .786,5$ \\
\hline
\end{tabular}

\section{Total Hasil Produksi}

Total hasil produksi atau total penerimaan yaitu seluruh produk yang dihasilkan dalam kegiatan pemeliharaan sapi ini yang diperoleh dengan cara menhitung harga jual sapi beserta feses.

Tabel 2. Rekapitulasi komponen hasil produksi tiap perlakuan selama penelitian (Rp)

\begin{tabular}{cccc}
\hline \multirow{2}{*}{ Perlakuan } & \multicolumn{3}{c}{ Rataan } \\
\cline { 2 - 4 } & Hasil penjualan sapi & Penjualan feses & Total hasil produksi \\
\hline P0 & 5.387 .250 & 95.250 & 5.482 .500 \\
P1 & 6.154 .500 & 116.750 & 6.271 .250 \\
P2 & 6.039 .000 & 131.720 & 6.170 .750 \\
\hline
\end{tabular}

Total hasil produksi penjualan sapi tertinggi pada P1 (pakan dengan 20\% pelepah kelapa sawit fermentasi) dengan rataan sebesar Rp.6.154.500,-, hal ini dikarenakan bobot 
badan akhir sapi pada perlakuan tersebut lebih tinggi dibandingkan dengan perlakuan lain. Hasil penjualan sapi terendah terdapat pada perlakuan P0 dengan rataan sebesar Rp 5.387.250,-, hal ini dikarenakan bobot badan akhir kelinci pada perlakuan tersebut merupakan bobot terendah pada keseluruhan perlakuan. Total hasil produksi tertinggi juga terdapat pada perlakuan P1 (pakan dengan 20\% pelepah kelapa sawit fermentasi) sebesar Rp. 6.271.250,-.

Tabel 3. Rekapitulasi rataan hasil penelitian

\begin{tabular}{cccc}
\hline \multirow{2}{*}{ Perlakuan } & \multicolumn{3}{c}{ Rataan } \\
\cline { 2 - 4 } & Laba/Rugi $(\mathrm{Rp})$ & R/C Ratio & IOFC (Rp) \\
\hline P0 & 1.570 .177 & 1,40 & 1.794 .927 \\
P1 & 2.146 .046 & 1,52 & 2.349 .296 \\
P2 & 2.008 .964 & 1,48 & 2.197 .214 \\
\hline
\end{tabular}

\section{Analisa laba/rugi}

Laporan laba-rugi (balance sheet) adalah laporan yang menunjukkan jumlah pendapatan yang diperoleh dan biaya-biaya yang dikeluarkan dalam suatu periode tertentu. Soekartawi (1986) menyatakan bahwa keuntungan (laba) suatu usaha ditentukan oleh selisih antara total penerimaan (total reserve) dan total pengeluaran (total cost) atau secara matematis dapat dituliskan $\mathrm{K}=$ TR-TC. Laba sebagai nilai maksimum yang dapat didistribusikan oleh suatu satuan usaha dalam suatu periode bagaimana pada awal periode. Menurut Kasmir dan Jakfar (2003), hasil usaha tersebut didapat dengan cara membandingkan penghasilan dan biaya selama jangka waktu satu tahun.

Laba tertinggi terdapat pada perlakuan P1(pakan dengan 20\% pelepah kelapa sawit fermentasi) dengan rataan sebesar Rp 2.146.046,- hal ini dikarenakan bobot badan sapi pada perlakuan tersebut lebih tinggi dan yang terendah pada perlakuan P0 (pakan dengan 25\% pelepah kelapa sawit segar) sebesar Rp 1.570.177,- hal ini dikarenakan bobot badan terendah dari keseluruhan perlakuan. Diketahui bahwa total biaya produksi lebih kecil dibandingkan dengan total hasil produksi. sehingga hal ini membuktikan bahwa analisis usaha sapi dengan menggunakan pakan pelepah kelapa sawit selama 14 minggu memberi keuntungan. Seperti diketui bahwa tujuan utama setiap peternakan adalah untuk mendapatkan keuntungan, maka dapat dilihat yang memberikan keuntungan yang terbaik adalah pada perlakuan P1 (pakan dengan $20 \%$ pelepah kelapa sawit fermentasi). Suatu usaha dikatakan untung apabila usaha 
tersebut mampu untuk menghasilkan keuntungan yang akan digunakan untuk menutup investasi yang dikeluarkan.

\section{R/C Ratio}

$\mathrm{R} / \mathrm{C}$ Ratio adalah nilai atau manfaat yang diperoleh dari setiap satuan biaya yang dikeluarkan. Dimana R/C Ratio diperoleh dengan cara membagikan total penerimaan (total reserve) dengan total pengeluaran(total cost).

$\mathrm{R} / \mathrm{C}$ ratio yang diperoleh menunjukkan bahwa pemberian pelepah kelapa sawit fermentasi dalam pakan sapi balilayak untuk jalankan karena rataan dari semua perlakuan memiliki hasil rataan $\mathrm{R} / \mathrm{C}>1$. Dengan nilai ratan $\mathrm{R} / \mathrm{C}$ ratio tertinggi terdapat pada perlakuan P1 (pakan dengan 20\% pelepah kelapa sawit fermentasi) yaitu sebesar 1,52 dan nilai rataan $\mathrm{R} / \mathrm{C}$ ratio terendah diperoleh pada perlakuan P1 sebesar 1,40. Kadariah (1987) menyatakan bahwa untuk mengetahui tingkat efisiensi suatu usaha dapat digunakan parameter yaitu dengan mengukur besarnya pemasukan dibagi besarnya korbanan, dimana bila :

$\mathrm{R} / \mathrm{C}$ Ratio $>1=$ efisien

$\mathrm{R} / \mathrm{C}$ Ratio $=1=$ impas

$\mathrm{R} / \mathrm{C}$ Ratio $<1=$ tidak efisien

Cahyono (2002) mengatakan bahwa return cost ratio ( $\mathrm{R} / \mathrm{C}$ ratio) bisa digunakan dalam analisis kelayakan usaha tani, yaitu perbandingan antara total pendapatan dan total biaya yang dikeluarkan dengan rumus:

$\mathrm{R} / \mathrm{C}$ ratio $=$ Total Pendapatan $(\mathrm{Rp})$

Total Biaya Produksi (Rp)

Berdasarkan Tabel 3 dapat dilihat nilai R/C Ratio yang diperoleh lebih besar dari 1 yang berarti pemeliharaan sapi bali dengan menggunakan pelepah kelapa sawit fermentasi layak untuk diterapkan pada periode pemeliharaan ternak sapi berikutnya. Semua perlakuan yang dipakai layak untuk diterapkan dan efisien untuk digunakan pada periode selanjutnya.

\section{IOFC (Income Over Feed Cost)}

IOFC adalah selisih antara pendapatan usaha peternakan terhadap total biaya pakan. Pendapatan ini merupakan perkalian antara nilai produksi peternakan dengan harga jual, sedangkan biaya pakan adalah jumlah biaya yang dikeluarkan untuk menghasilkan ternak 
tersebut (Prawirokusumo, 1990). Rataan IOFC terbesar terdapat pada perlakuan P1(pakan dengan 20\% pelepah kelapa sawit fermentasi) dengan rataan sebesar Rp 2.349.296,- dan rataan IOFC terkecil terdapat pada perlakuan P0 (pakan dengan 25\% pelepah kelapa sawit segar) dengan rataan sebesar Rp 1.794.927,--

Hal tersebut dapat diartikan bahwa penggunaan pelepah kelapa sawit fermentasi sebagai pakan sapi bali lebih menguntungkan dibandingkan dengan penggunaaan pelepah kelapa sawit segar sebagai pakan sapi bali karena pakan dengan pelepah keapa sawit fermentasi memiliki harga yang relaif lebih murah dengan tingkat konsumsi pakan yang lebih tinggi dibandingkan dengan pakan pelepah kelapa sawit segar sehngga lebih ekonomis untuk berproduksi dan diterapkan pada peternak.

Untuk menghasilkan suatu produksi kita harus mengetahui berproduksi secara teknis dan juga berproduksi dari segi ekonominya juga, beberapa tolak ukur yang dapat digunakan untuk berproduksi adalah IOFC (income over feed cost) atau selisih pendapatan usaha peternakan dengan biaya pakan. Pendapatan merupakan perkalian antara hasil produksi peternakan (kilogram hidup) dengan harga jual (Hermanto, 1996).

\section{KESIMPULAN}

Berdasarkan hasil penelitian dapat disimpulkan bahwa pelepah daun kelapa sawit yang difermentasi dengan Aspergillus niger dapat meningkatkan keuntungan peternak.

\section{DAFTAR PUSTAKA}

Budiono, 1990. Ekonomi Mikro. Seri Sinopsis Pengantar Ilmu Ekonomi No. 1. Edisi kedua, Cetakan ke II. BPFE, Yogyakarta.

Cahyono, B., 2002. Wortel Teknik Budidaya Analisa Usaha Tani. Kanisius, Yogyakarta.

Hanafiah, K. A. 2003. Rancangan Percobaan Teori dan Aplikasi. Raja rafindo.

Hermanto, F., 1996. Ilmu Usaha Tani. Penebar Swadaya, Jakarta.

Jalaludin, S., Y.W. Ho, N. Abdullah, and H.Kudo. 1991. Strategies for animal improvement in Southeast Asia. InUtilization of Feed Resources in Re-lation to Utilization and Physiology of Ruminants in the Tropics. Trop.Agric. Res. Series 25: 67-76.

Kadariah, 1987. Pengantar Evaluasi Proyek. Lembaga Penelitian Fakultas Ekonomi Universitas Indonesia, Jakarta.

Kasmir dan Jakfar, 2003. Study Kelayakan Bisnis. Kencana, Bogor. 
Prawirokusumo, S., 1990. Ilmu Gizi Komparatif. BPFE, Yogyakarta.

Soekartawi, J., L. Dillon, J. B. Hardaker dan A. Soeharjo, 1986. Ilmu Usaha Tani dan Penelitian Untuk Pengembangan Petani Kecil. Universitas indonesia-Press, Jakarta.

Umiyasih, U., Aryogi dan Y.N. Anggraeny, 2002. Pengaruh jenis suplementasi terhadap kinerja sapi PO yang mendapatkan pakan basal jerami padi fermentasi. ProsidingSeminar Nasional Teknologi Peternakan dan Veteriner. Pusat Penelitian dan Pengembangan Peternakan. Departemen Pertanian, Bogor. Hal: 139-142. 